\title{
The Effects of Environmental Performance and Environmental Information Disclosure on Financial Performance in Companies Listed on the Indonesia Stock Exchange
}

\author{
Msy. Mikial \\ Faculty of Economics, \\ Tridinanti University, Palembang, Indonesia \\ Taufiq Marwa \\ Faculty of Economics, \\ Sriwijaya University, Palembang, Indonesia \\ Luk Luk Fuada \\ Faculty of Economics, \\ Tridinanti University, Palembang, Indonesia \\ Inten Meutia \\ Faculty of Economics, \\ Sriwijaya University, Palembang, Indonesia
}

\begin{abstract}
The objective of this study was to examine the effects of environmental performance and environmental information disclosure on financial performance in companies listed on the Indonesia Stock Exchange. The population in this study amounted to 20 companies listed on the Indonesia Stock Exchange, issued an Annual Report and Sustainability Report and included in the Sustainability Disclosure Database of the Global Reporting Initiative (GRI). The data used in the form of secondary data obtained from annual reports and sustainability reports of companies listed on the Indonesia Stock Exchange from 2013 to 2016 . The numbers of observations in this study were 80. The analysis technique used was Partial Least Square (PLS). The novelty in this study is to measure environmental performance based on outcomes, namely environmental costs incurred by the company rather than compliance with regulations. The cost of a well-managed environment will improve environmental performance because there are efficient use of resources. The results of this study indicate that eenvironmental performance has no significant effect on financial performance, environmental information disclosure has a significant effect on financial performance. Disclosure of environmental information has a negative effect on financial performance, it shows that if the disclosure of environmental information is more equipped and in accordance with the disclosure guidelines, the cost is not small so that it will reduce financial performance. Research limitation that environmental costs is difficult to obtain so that the population is limited to companies listed on the IDX that have a Sustainability Report and are included in the Sustainability Disclosure Database of the Global Reporting Initiative. Disclosure of environmental information which is the result of the implementation environmental management accounting has not been done by all companies, because it is still voluntary is not mandatory. The suggestion of the research, the Indonesian Accountants Association is expected to form separate standards for measuring and reporting environmental cost information and standardized. For other researchers who are interested in researching environmental accounting can develop other variables for a longer time and the number of companies that publish more Sustainability Reporting.
\end{abstract}

Keywords: Environmental Performance, Environmental Information Disclosure, Financial Performance 


\section{INTRODUCTION}

Indonesian public awareness on the importance of the environment starts to grow slowly. People who believe that the environment carried out by the company focuses more on using technology as efficiently as possible and unwittingly ignoring environmental aspects. The government has also established regulations on environmental management, but there are still many companies that contribute to the problem of environmental pollution.

In recent years, the concept of sustainability has become a major issue of the company's development. This concept arises due to the demands and expectations of the community about the company's role in society. Sustainability Reporting is a trend and need for companies to inform about economic, social performance and its environment at the same time to all stakeholders of the company. Sustainability Reporting contains not only financial performance information but also non-financial information consisting of information on social and environmental activities that enable companies to grow sustainably.

The company has an interest in improving environmental performance with the ultimate goal to increase the profits gained, as stated by Nakao, Amano, Matsumura, Genba, \& Nakano, (2007), (Suratno, Darsono, \& Mutmainah, 2006) and (Earnhart \& Lizal, 2010) there is a positive influence of the company's environmental activities (environmental performance) on financial performance. According to Moneva \& Ortas, (2010) companies with good environmental performance will be followed by a good financial position, because it increases efficiency, consolidates the financial situation and meets the demands of the company's stakeholders. Improved environmental performance will lead to the use of cost-effective organizational resources so that businesses that are environmentally responsible will be able to report higher returns that lead to enhanced value than companies that are less responsible (Porter \& Linde, 1995). Contrary to the research of Walker \& Wan, (2012) and (Horváthová, 2010) who found that environmental performance has a negative effect on financial performance. Likewise with the results of (Dragomir, 2010) and (Gibson Nyirenda, 2013) research which states that no relationship was found between performance environments with financial performance.

Information on environmental performance needs to be disclosed to the community, in these case stakeholders, although the nature of its disclosure is still voluntary. With the disclosure of environmental information, the company's image is expected to increase and increase stakeholder perceptions, which will further improve the company's financial performance. (Oba, Fodio, 2012), (Ong, Tho, Goh, Thai, \& Teh, 2016) and Mahmes, (2016) state that there was a positive and significant relationship between the quality of environmental information disclosure on financial performance, while (Malarvizhi, 2016) find out no significant relationship between the level of environmental disclosure and the company's financial performance.

The novelty in this study is to measure environmental performance based on outcomes, namely environmental costs incurred by the company rather than compliance with regulations. The cost of a well-managed environment will improve environmental performance because there are efficient use of resources. In the end it will improve the company's financial performance. Companies with good environmental performance will disclose environmental information to meet stakeholder demands.

The objective of this study is to analyze and examine empirically the effect of environmental performance and environmental information disclosure on financial performance at 
companies on the Indonesia Stock Exchange that publish Sustainability Reporting. This research was developed through explanation and justification of data collected and continued with results and implications.

\section{LITERATURE REVIEW, DEVELOPMENT OF THEORY AND HYPOTHESES \\ Stakeholder Theory}

Stakeholder theory is used as a basis for analyzing groups for companies to be responsible. Stakeholder theory introduced by Freeman (1984) states that the company is an organ that deals with other interested parties, both inside and outside the company. So the success of a company depends heavily on the success of management in managing relationships with its stakeholders.

The concept of stakeholders is described by Evan and Freeman (1993) as the following two principles:

- The principle of company legitimacy. Corporations must be managed for the benefit of stakeholders : customers, suppliers, owners, employees and local communities. The rights of these groups must be ensured, and furthermore, groups must participate, in a sense, in decisions that substantially affect their welfare.

- Fiduciary principles of stakeholders. Management bears fiduciary relationships to stakeholders and corporations as abstract entities. In this case it must act in the interests of the stakeholders as their agent, and must act in the interests of the corporation to ensure the survival of the company, maintain their existence in the long term.

\section{Environmental Performance}

Bennett and James (1999) emphasize environmental performance as the company's achievement in managing any interaction between the company's activities, products or services and the environment.

Enviromental performance is measured by environmental costs, namely company expenditures for mitigation and environmental protection show how effectively organizations use resources to improve performance. These expenditures allow organizations to assess the value of investments for complex organizations or technologies (GRI, 2013). Environmental costs can be expressed as costs to minimize environmental impacts caused by the company's business activities and costs associated with it. Environmental costs include all costs incurred due to the use of inputs (energy, water, materials) and the disposal of non-product outputs (waste and emissions) plus other costs associated with efforts to protect the environment. Environmental costs are basically related to the costs of important products, processes, systems or facilities for better management decisions (Ikhsan, 2009).

\section{Environmental Information Disclosure}

Environmental information disclosure are: "Environmental disclosure was taken to comprise disclosure relating to the company's attitude, policy or behavior towards its environmental impact, emissions, pollution, cleaning up (after pollution), re-landscaping or energy efficiency (that was not intended as an explicit economic message)" (Campbell, 2004)

The disclosure of environmental information in the annual report is one of the effective disclosure methods because this report is the main source of information for investors, creditors, customers, employees, environmental groups and government (Patten, 1992). This report is also a medium for companies to publish all information about companies that need to be known by the company to the public, including information about the environment, which is 
issued periodically, made by almost all companies, and easy to read and compare. (Wang, 2016) states that the disclosure of environmental information is beneficial for relevant government authorities, practitioners, and academics in helping to understand the value relevance of environmental information disclosure and corporate governance in decision making for various purposes such as investment, financing, consumption, and labor supply.

The Sustainability Reporting Guidelines, also referred to as the Global Reporting Initiative (GRI), are the most widely used guidelines for environmental information disclosure. Global Reporting Initiative (GRI) G4 is an ongoing reporting guideline that contains the latest disclosure of environmental information. Sustainability reporting helps organizations to set goals, measure performance, and manage change in order to make their operations more sustainable. A sustainability report conveys disclosures about the impact of the organization whether positive or negative - on the environment, society and the economy. In an effort to make it happen, sustainability reporting makes abstracts real and concrete, thus helping in understanding and managing the impact of sustainable development on organizational activities and strategies. Disclosures and metrics that are agreed internationally allow information contained in sustainability reports to be accessed and compared, so as to provide additional information to stakeholders to make decisions (GRI, 2013)

\section{Financial Performance}

Financial performance is a description of the company's financial condition in a certain period of both aspects of fund raising and channeling of funds, which is usually measured by indicators of capital adequacy, liquidity and profitability (Werner et al., 2013). Financial performance describes the work performance that has been achieved by the company in a certain period and contained in the company's related financial statements. Return on Investment (ROI), Return on Assets (ROA), and Return on Equity (ROE) are the most commonly used measures of profitability. ROI and ROA are often used interchangeably because they refer to the same thing, namely the ratio between earnings and assets owned, while ROE refers to the amount of the company's equity.

(Ezejiofor, 2016) found that environmental costs have no effect positive on the income of corporate organizations in Nigeria. In addition, environmental costs also positively influence the formation of corporate earnings, and there is a significant influence of sustainability policies, strategies and operations on financial performance. Birkin \& Woodward, (1997) state that there is a relationship between environmental performance and financial performance through cost efficiency generated by good environmental performance. Nakao et al., (2007) research results stated that the company's environmental performance has a positive influence on its financial performance and is verified more clearly when information about the company's response to business Environmental services are included with information about environmental management activities. Clarkson, Overell, \& Chapple, (2011) research shows that not only companies with higher pollution trends reveal more environmental information, poor environmental performance (high pollutant companies) make voluntary disclosure on environmental performance. Thus, high environmental reporting does not necessarily mean high environmental performance. The results of (Nor, Bahari, Adnan, Kamal, \& Ali, 2016) state that there is a significant relationship between total environmental disclosure and profit margins. Disclosure of environmental information will benefit the market and the ability to benefit from investments in environmental improvement. However, the findings for the other three variables, namely ROA, ROE, and EPS show no significant relationship between total environmental disclosure. 


\section{Development of Theory}

Contemporary economists state that companies not only create profit or welfare for shareholders, but also provide welfare to all stakeholders. This means that companies are not only oriented to maximizing profits to shareholders, but companies are also required to contribute and commit to social and environmental activities to their stakeholders. Stakeholder theory assumes that the existence of a company is determined by its stakeholders. According to stakeholder theory, organizations/companies will voluntarily disclose information about environmental and social performance. Companies have a tendency to satisfy stakeholders because they need support to improve company performance and continue operations. To meet the demands of stakeholders for environmentally friendly products, the company strives to make environmental cost efficiency efforts that reflect the company's environmental performance, and try to disclose its environmental information with the aim of meeting stakeholder demands. The company seeks to improve environmental performance and disclose environmental information in sustainability reports with the aim of gaining legitimacy from the community.

\section{Hypothesis:}

H1: Environmental performance have a positive effect on financial performance in companies listed on the Indonesia Stock Exchange.

H2: Environmental information disclosure have a positive effect on financial performance in companies listed on the Indonesia Stock Exchange.

\section{Data Sources and Data Collection}

\section{METHODOLOGY}

Data sources in the form of secondary data come from electronic publications that are accessed from internet. The data collection method used in this study is documentation. Data obtained from various sources include data from sustainability reports and company annual reports on the Indonesia Stock Exchange and in the Sustainability Disclosure Database of the Global Reporting Initiative (GRI), from literature, journals and other sources related to problems in research.

\section{Population}

The population of this study is all companies registered in the 2013-2016 Indonesia Stock Exchange Which have following criteria:

(1) Issue full Annual Report and Suitability Report

(2) Having data regarding disclosure of environmental information

(3) Having data on environmental costs

(4) Included in thev Sustainability Disclosure Database from the Global Reporting Initiative (GRI)

Based on the predetermined criteria, the population 20 companies registered in the Indonesian Securities Exchange, publishes the Annual Report and Sustainability Report and is included in the Sustainability Disclosure Database of the Global Reporting Initiative (GRI) for the period 2013-2016 (4 years), resulting in 80 observations. 
Table 3.1

List of Companies Registered on the IDX In 2017

\begin{tabular}{|c|c|l|}
\hline No & Code & \multicolumn{1}{|c|}{ Company Name } \\
\hline 1 & ANTM & Aneka Tambang (Persero) Tbk \\
\hline 2 & ASII & Astra International Tbk \\
\hline 3 & ELSA & Elnusa Tbk \\
\hline 4 & INCO & Vale Indonesia Tbk \\
\hline 5 & INDR & Indo Rama Synthetic Tbk \\
\hline 6 & INTP & Indocement Tunggal Prakasa Tbk \\
\hline 7 & ITMG & Indo Tambangraya Megah Tbk \\
\hline 8 & PTBA & $\begin{array}{l}\text { Tambang Batubara Bukit Asam } \\
\text { (Persero) Tbk }\end{array}$ \\
\hline 9 & PTRO & Petrosea Tbk \\
\hline 10 & SMCB & Holcim Indonesia Tbk \\
\hline 11 & SMGR & Semen Indonesia (persero) Tbk \\
\hline 12 & TINS & Timah (Persero) Tbk \\
\hline 13 & WTON & Wijaya Karya Beton Tbk \\
\hline 14 & PGAS & $\begin{array}{l}\text { Perusahaan Gas Negara (Persero) } \\
\text { Tbk }\end{array}$ \\
\hline 15 & UNTR & United Tractors Tbk \\
\hline 16 & BBNI & Bank Negara Indonesia Tbk \\
\hline 17 & BMRI & Bank Mandiri (persero) Tbk \\
\hline 18 & GIAA & Garuda Indonesia (persero) Tbk \\
\hline 19 & BNII & PT Bank Mybank Indonesia Tbk \\
\hline 20 & BBRI & $\begin{array}{l}\text { Bank Rakyat Indonesi (persero) } \\
\text { Tbk }\end{array}$ \\
\hline & & Sources www Idxcoid \\
\hline
\end{tabular}

Sources : www.idx.co.id

\section{Operational Definition and Variable Measurement}

The variables in this study consisted of :

\section{Environmental performance $\left(X_{1}\right)$}

Environmental performance is activities carried out by companies that are directly related to the surrounding natural environment. This variable is measured using environmental costs, namely costs to minimize environmental impacts caused by the company's business activities and costs associated with it. Environmental costs are measured by the company's total environmental expenditure and investment protection based on guidelines from GRI G4 En-31.

\section{Disclosure of environmental information $\left(\mathrm{X}_{2}\right)$}

Disclosure of environmental information is a set of past, present and future information regarding company activities and environmental performance including information about financial implications resulting from environmental management decisions or actions by the company. This variable is measured by disclosures based on the dimensions and indicators of Global Reporting Initial G4 (2013) as many as 34 indicators, which consist of aspects of material, energy aspects, water aspects, biodiversity aspects, emissions aspects, effluent and waste aspects, product and service aspects, compliance aspects, transportation aspects, other aspects, and aspects of supplier assessment on the environment. By using a checklist compiled based on disclosure indicators to calculate how much was disclosed compared to what should be disclosed.

\section{Financial Performance (Y)}

Finance is a measure of the company's success in monetary units. The indicator used to measure financial performance is the company's profitability, namely Return on Equity (ROE), which describes the profit ratio obtained by equity owned by the company. 


\section{Technique of Analysis}

The research model submitted to be tested is as follows:

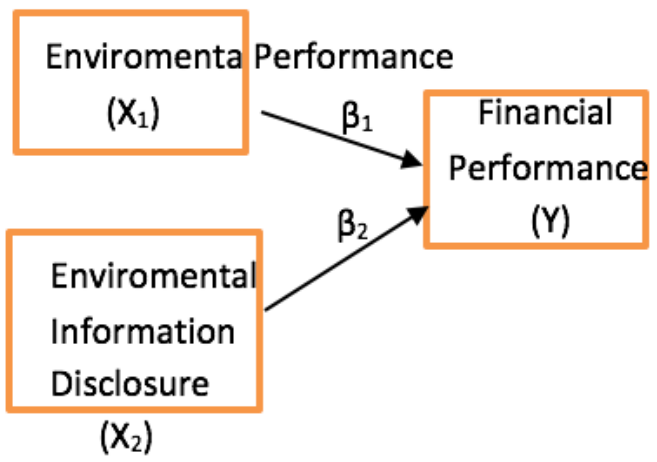

$$
\begin{aligned}
& \text { Equation: } \\
& \mathrm{Y}=\beta_{1} \mathrm{X}_{1}+\beta_{2} \mathrm{X}_{2}+\varepsilon
\end{aligned}
$$

The analytical tool uses Smart PLS software. Partial Least Square (PLS) software is an analytical method that is soft modeling because it does not assume the data must be with a certain measurement scale, which means the number is small (under 100 samples).

\section{Path Coefficient}

\section{RESULT}

The efficiency of exogenous variable paths to endogenous variables can be seen in the Table 1 below:

Table 1 Path Coefficient

\begin{tabular}{|l|c|c|c|c|c|}
\hline & $\begin{array}{c}\text { Original } \\
\text { Sample (0) }\end{array}$ & $\begin{array}{c}\text { Sample } \\
\text { Mean (M) }\end{array}$ & $\begin{array}{c}\text { Standard } \\
\text { Error (STERR) }\end{array}$ & $\begin{array}{c}\text { t-Statistics } \\
\text { (|O/STERR|) }\end{array}$ & $\begin{array}{c}\text { P } \\
\text { Values }\end{array}$ \\
\hline $\begin{array}{l}\text { Environmental } \\
\text { Performance } \\
\text { (X1) -> Financial } \\
\text { Performance (Y) }\end{array}$ & 0,139 & 0,146 & 0,098 & 1,426 & 0,077 \\
\hline $\begin{array}{l}\text { Environ mental } \\
\text { Informa tion } \\
\text { Disclosure (X2) - } \\
\text { > Financial } \\
\text { Performance(Y) }\end{array}$ & $-0,265$ & $-0,270$ & 0,090 & 2,944 & 0,002 \\
\hline
\end{tabular}

\section{The Effects of Environmental Performance on Financial Performance}

Based on the estimation results shown in Table 1, it can be seen that Environmental performance (X1) does not affect financial performance (Y). This condition is characterized by a statistical $t$ value of 1.426 and a p value of 0.077 not significant at the level of $\alpha 5 \%$.

The results of this study were not in line with some of the results of previous studies which stated that environmental performance has an effect on financial performance, such as the results of research by (Nakao et al., 2007), (Suratno et al., 2006), (Earnhart \& Lizal, 2010) and (Moneva \& Ortas, 2010). The results of their research can explain that companies with better environmental performance will increase profitability.

The results of previous studies to measure environmental performance use many measures of compliance with regulations, while this study uses an outcomes approach in the form of environmental costs incurred by the company covering total environmental expenditure and investment protection as environmental performance. In this study the environmental performance with proxy environmental costs issued by the company apparently can not affect 
financial performance. The results of this study are in line with the research conducted by (Dragomir, 2010) and (Nyirenda, Ngwakwe, \& Ambe, 2013) which states that no relationship was found between environmental performance and financial performance.

In fact, not many companies are aware of the importance of environmental performance to be able to improve the company's financial performance. Companies in Indonesia in particular, not many separate the costs associated with the environment in individual items in the cost group and still include them in factory overhead costs, so that company management will experience difficulties when making decisions relating to environmental conservation. In reality environmental management accounting facilitates the management of environmental costs and reduces costs through making connections between costs and the underlying activities (Noodezh \& Moghimi, 2015).

The environmental cost approach with the environmental quality cost model adopted by the quality cost model by (Hansen, Don R; Mowen, 2007) allows companies to prioritize prevention of environmental damage before it occurs compared to handling if environmental damage has occurred. This is also in line with (Al-tuwaijri, Christensen, \& Ii, 2004) which states that managers must change their strategies regarding environmental performance, namely from the emphasis on the costs of handling pollution and environmental damage (pollution abatement costs) to be costs for prevention of pollution and environmental damage (pollution prevention costs). (Moneva \& Ortas, 2010) states that companies with good environmental performance have good financial performance in the future. This is because good environmental performance can improve efficiency, consolidate financial situations and meet the demands of corporate stakeholders. Thus, if managers ignore environmental factors when designing strategic policies, the company will lose competitiveness in the long run. This is in accordance with stakeholder theory which states that a company is an organ that deals with other interested parties, both inside and outside the company, so the existence of the company is determined by stakeholders.

\section{The Effects of Environmental Performance and Environmental Information Disclosure on Financial Performance}

Disclosure of environmental information $\left(\mathrm{X}_{2}\right)$ affects financial performance $(\mathrm{Y})$. This condition is marked by a statistic value of 2.944 and a p value of $0.002<0.05$. The direction of its influence is negative, meaning that the more complete the disclosure of environmental information, the financial performance will decrease.

This condition indicates that environmental information disclosure causes the declining components of financial performance. In the initial and short-term stages, disclosure of environmental information weighs on the company so that it incurs additional costs and disrupts the company's financial performance.

The results of this study are not in line with the previous research conducted by Mahmes, (2016) and Nor et al., (2016) that there is a significant influence / relationship between total environmental disclosure and profit margins. By disclosing information about the environment the company will gain market benefits and the ability to benefit from investments in environmental improvement, so that its financial performance increases. Stakeholder theory states that information is one of the media to obtain support and manage relationships with stakeholders (Gray, 1994). Environmental information disclosure is often used by companies to create a good image in the eyes of stakeholders, especially customers and investors. If the customer has a good image about the company, it is likely that it will affect his behavior in 
buying company products so that it is expected to improve financial performance through increased sales (Ling, 2007). Previous theory and research cannot be proven in this study because of the fact that even companies with very low levels of environmental information disclosure can increase sales. This study supports research from (Malarvizhi, 2016) whose results show that there is no significant relationship between the level of environmental disclosure and company performance. Companies that do not generate large profits also disclose information about the environment. In order to maintain a global environment, companies must disclose environmental information even though their financial performance is not good.

\section{Conclusions}

\section{CONCLUSIONS, LIMITATIONS AND RECOMMENDATIONS}

Based on the formulation of the problem, the formulation of the hypothesis and the results of the study, the following conclusions can be drawn: Environmental performance has no significant effect on financial performance, while environmental information disclosure has a significant effect on financial performance. In fact, not many companies are aware of the importance of environmental performance to be able to improve the company's financial performance. The disclosure of environmental information has a negative effect on financial performance, it shows that if environmental information disclosure is more completed it will reduce financial performance. This condition indicates that disclosure of environmental information causes the deciding component of financial performance. Disclosure of environmental information in the initial stages burdens the company with additional costs and this can reduce the company's financial performance.

\section{Limitations}

This study has the following limitations: Environmental cost data is difficult to obtain so that the study population is limited to companies listed on the IDX that have a Sustainability Report and are included in the Sustainability Disclosure Database of the Global Reporting Initiative (GRI). Disclosure of environmental information as a result of the implementation of environmental management accounting has not been carried out by all companies responsible for the public, because its nature is still voluntary, it is not an obligation.

\section{Recommendations}

Based on the conclusions, it is expected that Ikatan Akuntan Indonesia (IAI) as an accounting profession organization in Indonesia is expected to be able to formulate measurement and reporting standards for environmental cost information so that reporting and disclosure can be generated separate and standardized environmental information, so that it no longer becomes voluntary disclosure but mandatory disclosure for each company. For other researchers who are interested in researching environmental accounting can develop other variables such as environmental regulation, environmental audit, organizational commitment, and others with a more comprehensive dimension and with a longer span of time and the number of companies that publish more Sustainability Reporting.

\section{References}

Al-tuwaijri, S. A., Christensen, T. E., \& Ii, K. E. H. (2004). The relations among environmental disclosure , environmental performance, and economic performance : a simultaneous equations approach. Society, 29(801), 447-471. https://doi.org/10.1016/S0361-3682(03)00032-1

Birkin, F. K., \& Woodward, D. G. (1997). Accounting for the sustainable corporation. Environmental Management and Health, 8(2), 67-72. https://doi.org/10.1108/09566169710166557

Campbell, D. (2004). A longitudinal and cross-sectional analysis of environmental disclosure in UK companies - A research note. British Accounting Review. https://doi.org/10.1016/j.bar.2003.09.001 
Clarkson, P. M., Overell, M. B., \& Chapple, L. (2011). Environmental Reporting and its Relation to Corporate Environmental Performance. Abacus. https://doi.org/10.1111/j.1467-6281.2011.00330.x

Dragomir, V. D. (2010). Environmentally sensitive disclosures and financial performance in a European setting. Journal of Accounting \& Organizational Change, 6(3), 359-388. https://doi.org/10.1108/18325911011075222

Earnhart, D., \& Lizal, L. (2010). The Effect of Corporate Environmental Performance on Financial Outcomes Profits, Revenues, and Costs : Evidence from the Czech Transition Economy* Dietrich Earnhart \# The Effect of Corporate Environmental Performance on Financial Outcomes - Profits ,. Environmental \& Resource Economics, European Association of Environmental and Resource Economists, 46(3), 1-44.

Ezejiofor, R. A. (2016). Effect of Sustainability Environmental Cost Accounting on Financial Performance of Nigerian Corporate Organizations. International Journal of Scientific Research and Management, (April). https://doi.org/10.18535/ijsrm/v4i8.06

Gibson Nyirenda. (2013). No Title.

Gray, R. H. (1994). Corporate Reporting for Sustainable Development: Accounting for Sustainability in 2000 AD. Environmental Values, 3(1), 17-45. https://doi.org/10.3197/096327194776679782

GRI. (2013). Pedoman Pelaporan Keberlanjutan G4. Global Reporting Initiative. Retrieved from www.globalreporting.org

Hansen, Don R; Mowen, M. M. (2007). Managerial Accounting. aaajournals.org. https://doi.org/10.1111/j.1751908X.2002.tb00883.x

Horváthová, E. (2010). Does environmental performance affect financial performance? A meta-analysis. Ecological Economics, 70(1), 52-59. https://doi.org/10.1016/J.ECOLECON.2010.04.004

Ling, Q. (2007). Competitive strategy, voluntary environmental disclosure strategy, and voluntary environmental disclosure quality. ProQuest Dissertations and Theses.

Mahmes, K. (2016). Corporate Environmental Disclosure and Economic Performance of Companies in the Libyan Manufacturing Sector. International Journal of Economics and Finance Studies, 8(2), 1309-8055. Retrieved from http://www.sobiad.org/ejournals/journal_ijef/archieves/IJEF-2016_2/kemal.pdf

Malarvizhi, P. (2016). Link between Corporate Environmental Disclosure and Firm Performance - Perception or Reality. Accounting, Organizations and Society, 5(3), 1-34.

Moneva, J. M., \& Ortas, E. (2010).

Corporate environmental and financial performance: a multivariate approach. Industrial Management \& Data Systems, 110(2), 193-210. https://doi.org/10.1108/02635571011020304

Nakao, Y., Amano, A., Matsumura, K., Genba, K., \& Nakano, M. (2007). Relationship between environmental performance and financial performance: An empirical analysis of Japanese corporations. Business Strategy and the Environment. https://doi.org/10.1002/bse.476

Noodezh, H. R., \& Moghimi, S. (2015). Environmental Costs and Environmental Information Disclosure in the Accounting Systems. International Journal of Academic Research in Accounting Finance and Management Sciences, 5(1), 13-18. https://doi.org/10.6007/IJARAFMS/v5-i1/1412

Nor, N. M., Bahari, N. A. S., Adnan, N. A., Kamal, S. M. Q. A. S., \& Ali, I. M. (2016). The Effects of Environmental Disclosure on Financial Performance in Malaysia. Procedia Economics and Finance, 35(October 2015), $117-126$. https://doi.org/10.1016/S2212-5671(16)00016-2

Nyirenda, G., Ngwakwe, C. C., \& Ambe, C. M. (2013). Performance in a South African Mining Firm. Managing Global Transitions.

Oba, Fodio, S. (2012). The Value Relevance of Environmental Responsibility Information Disclosure ...: EBSCOhost. Acta Universitatis Danubius: Oeconomica., 8(6), 99-112. Retrieved from http://web.b.ebscohost.com/ehost/detail/detail?vid=105\%7B\&\%7Dsid=cab002ee-11b2-4e91-96d1c794a04685d8\%7B\%25\%7D40sessionmgr106\%7B\&\%7Dhid=102\%7B\&\%7Dbdata=JnNpdGU9ZWhvc3QtbGl2ZQ \%7B\%25\%7D3D\%7B\%25\%7D3D\%7B\#\%7DAN=88361949\%7B\&\%7Ddb=buh

Ong, T. S., Tho, H. S., Goh, H. H., Thai, S. B., \& Teh, B. H. (2016). The relationship between environmental disclosures and financial performance of public listed companies in Malaysia. International Business Management. https://doi.org/10.3923/ibm.2016.461.467 
Patten, D. M. (1992). Intra-industry environmental disclosures in response to the Alaskan oil spill: A note on legitimacy theory. Accounting, Organizations and Society. https://doi.org/10.1016/0361-3682(92)90042-Q

Porter, M. E., \& Linde, C. van der. (1995). Toward a New Conception of the Environment-Competitiveness Relationship. Journal of Economic Perspectives, 9(4), 97-118. https://doi.org/10.1257/jep.9.4.97

Suratno, I. B., Darsono, \& Mutmainah, S. (2006). Pengaruh Environmental Performance Terhadap Environmental Disclosure dan Economic Performance (Studi Empiris pada Perusahaan Manufaktur yang Terdaftar di Bursa Efek Jakarta Periode 2001-2004). Simposium Nasional 9 Padang.

Walker, K., \& Wan, F. (2012). The Harm of Symbolic Actions and Green-Washing: Corporate Actions and Communications on Environmental Performance and Their Financial Implications. Journal of Business Ethics, 109(2), 227-242. https://doi.org/10.1007/s10551-011-1122-4

Wang, M. C. (2016). The relationship between environmental information disclosure and firm valuation: the role of corporate governance. Quality and Quantity, 50(3), 1135-1151. https://doi.org/10.1007/s11135-015-0194-0

Werner, M., Rusdiana, Purwanto, Jumingan, Juliana, John, ... Fahmi, I. (2013). Analisa Laporan Keuangan. Jurnal Of Business And Banking. 